\title{
GTAW of 12\% Supermartensitic Stainless Steel Using 625 Nickel Alloy as Filler Metal
}

\author{
S.S.M. Tavares ${ }^{a, b *}$ (1), J.C. Payão ${ }^{c}$, J.M. Pardal ${ }^{\text {,d }}$, A.S.M. Cardoso ${ }^{d}$, R. Chales ${ }^{d}$ (i) \\ ${ }^{a}$ Universidade Federal Fluminense, Departamento de Engenharia Mecânica, Rua Passo da Pátria, 156, \\ 24210-240, Niterói, RJ, Brasil. \\ ${ }^{b}$ Centro Federal de Educação Celso Suckow da Fonseca, Programa de Pós-Graduação em Engenharia \\ Mecânica e Tecnologia de Materiais (PPEMM), Rio de Janeiro, RJ, Brasil. \\ ${ }^{c}$ Universidade Federal do Rio de Janeiro, Programa de Pós-Graduação em Engenharia Metalúrgica e \\ de Materiais, Rio de Janeiro, RJ, Brasil. \\ ${ }^{d}$ Universidade Federal Fluminense, Programa de Pós-Graduação em Engenharia Mecânica (PGMEC), \\ Rua Passo da Pátria, 156, 24210-240, Niterói, RJ, Brasil.
}

Received: March 14, 2021; Revised: May 19, 2021, ano; Accepted: June 11, 2021

\begin{abstract}
Supermartensitic steels represent a new sub-class of martensitic stainless steels with higher toughness and corrosion resistance than conventional grades. These properties were improved by the drastic reduction of carbon content, and the addition of nickel and molybdenum. These chemical composition changes also increased the weldability of these steels, since the soft and ductile martensite formed is not susceptible to cold cracking during welding. However, post weld heat treatment may be necessary for uses in sour, aggressive and embrittlement environments. This work investigates the mechanical properties of a weld produced by gas tungsten arc welding (GTAW) of a pipe of $12 \% \mathrm{Cr}$ supermartensitic stainless steel with 625 nickel alloy as filler metal. The response of the weld metal to post weld heat treatments at $650^{\circ} \mathrm{C}$ was also evaluated.
\end{abstract}

Keywords: GTAW, Supermartensitic, Stainless Steel, Post weld heat treatment.

\section{Introduction}

Supermartensitic Stainless Steels (SMSS) were developed from the basic composition of $11-13 \% \mathrm{Cr}$ conventional martensitic stainless steels through important modifications in the chemical composition ${ }^{1}$. The carbon contents were reduced to extra low levels $(<0.03$ wt.\%), while nickel was added as austenitizing element. Corrosion resistance and mechanical properties were improved by Mo up to $2.0 \mathrm{wt} \%$. Nb, $\mathrm{V}$ and/or Ti were added to some grades to form carbides and nitrides and improve mechanical properties and corrosion resistance ${ }^{2}$.

Steels with such complex chemical compositions may present a microstructure with not only martensite but also austenite and ferrite phases, depending on the heat treatment. For instance, quenching and tempering at $650^{\circ} \mathrm{C}$ produced a microstructure of tempered martensite, reverse austenite, and fine carbides, with excellent low temperature toughness in a Ti-alloyed $12-13 \% \mathrm{Cr} \mathrm{SMSS} \mathrm{steel}^{3,4}$. Delta ferrite islands may be found in the heat affected zone (HAZ) and in higher $\mathrm{Cr}$ and Mo grades. However, the increase of delta ferrite $(\delta)$ in supermartensitic steel decreases the impact toughness of the HAZ ${ }^{5}$.

The main applications of SMSS in oil and gas industries are in oil country tubular goods (OCTG), where a small number of joints are produced by weld, and the majority is threaded. On the other hand, the joints in pipelines for oil and gas transportation are all made by welding. For this reason, some important research works about welding and

*e-mail: ssmtavares@terra.com.br weldability of supermartensitic stainless steels have been developed ${ }^{6-13}$, some of them envisaging new applications for this type of steel, such as in pipelines.

According to Lippold and Kotecki ${ }^{1}$, SMSS may be welded with similar feed metal or with austeno-ferritic steel (duplex or superduplex). The works of Pereda et al. ${ }^{14}$, Zappa et al. ${ }^{7}$, Ramirez ${ }^{8}$, Thibault et al. ${ }^{9}$ and Neubert et al ${ }^{10}$ are examples of researches about welds produced with similar feed metal. The main difficulty is to find a commercial feed metal which matches perfectly with the composition of the SMSS to be welded.

Supposedly, the extra low carbon content of SMSS gives a better weldability to these steels, since the soft and ductile martensite formed is not susceptible to cold cracking during welding ${ }^{12}$. However, post weld heat treatment (PWHT) may be necessary for components used in aggressive and sour environment. According to NACE $0175 /$ ISO 15156 -Part $3^{15}$ the maximum hardness of "super 13" UNS S41426 (Ti-alloyed) in sour service is $27 \mathrm{HRC}$. This limit is frequently exceeded in the HAZ ${ }^{13}$.

The goals of PWHT are the reduction of peak of hardness in the heat affected zone (HAZ) and stress relief ${ }^{7-9}$. Although Neubert et al. ${ }^{10}$ have found a slight increase of hardness of $12 \% \mathrm{Cr}$ SMSS with short time post weld tempering in the $630-640^{\circ} \mathrm{C}$ range, other works reported the decrease of the HAZ hardness with PWHT in the $600-650^{\circ} \mathrm{C}$ range ${ }^{7-9,11}$. Divya et al. ${ }^{16}$ obtained significant reduction of hardness in weld metal obtained with ER 414NiMo through single and double PWHT. Bilmes et al. ${ }^{17}$ reported the increase of 
toughness with double tempering treatments and attributed to the increase of reverse austenite and the TRIP effect. On the other hand, double tempering makes the cost and duration of PWHT increase, and the difference of mechanical properties to the single tempered material may not be significant ${ }^{4}$.

Woollin ${ }^{13}$ studied the short duration PWHT in joints of SMSSs with similar feed metal and with superduplex stainless steel (SDSS). The PWHT at $650^{\circ} \mathrm{C}$ for 5 minutes was effective to reduce the risk of intergranular stress corrosion cracking (IGSCC) ${ }^{13}$, but the peak of hardness in the HAZ was not significantly reduced. The IGSCC is believed to be associated to sensitization of the HAZ, mainly in the root pass region, and the PWHT promotes a healing effect by chromium diffusion. Short duration PWHT is specially recommended to welds where SDSS is used as filler metal to avoid intermetallics precipitation ${ }^{1,11,13}$.

In a previous work of our group, the microstructure and mechanical properties of a SMSS welded with superduplex stainless steel feed metal ${ }^{11}$ were investigated. The results showed that the PWHT at $650^{\circ} \mathrm{C}$ were effective in reduce the peak of hardness in the HAZ, but the increase of time at $650^{\circ} \mathrm{C}$ caused embrittlement of the weld metal due to precipitation of intermetallic compounds.

In this work, a pipe of Ti-alloyed $12 \% \mathrm{Cr}$ SMSS was welded with nickel alloy 625 (ERNiCrMo-3). The response of the microstructure and mechanical properties to PWHT at $650^{\circ} \mathrm{C}$ was investigated and compared to previous works.

\section{Experimental}

The base metal was a SMSS UNS S41426 pipe with $200 \mathrm{~mm}$ of diameter and $10 \mathrm{~mm}$ of thickness. Before welding the tube was quenched and tempered at $620 \pm 10^{\circ} \mathrm{C}$. Two parts of $200 \mathrm{~mm}$ of length were circumferentially welded, without pre-heating. The filler metal used was certified AWS A5.14 ERNiCrMo3. Table 1 shows the chemical compositions of the base metal. A V-bevel with $70^{\circ}$ was prepared by machining for multi-pass welding. The welding was performed with GTAW manual process, with direct polarity, and maximum inter-pass temperature $150^{\circ} \mathrm{C}$. The welding was completed with 13 passes, using wires with $2.4 \mathrm{~mm}$ (root passes) and $3.2 \mathrm{~mm}$ (filling and cap passes). The heat input was controlled between 1.3 and $1.7 \mathrm{~kJ} / \mathrm{mm}$.

After welding the joint was inspected by radiographic non-destructive test and no defects were observed. The joint was divided into specimens for hardness measurements, Charpy impact test, tensile tests and microstructural characterization. Some specimens were tested in the as welded condition while other specimens were subjected to PWHT at $650^{\circ} \mathrm{C}$ for 15 minutes, 30 minutes, 45 minutes and 60 minutes. Table 2 shows samples identification and respective processing conditions. The post weld heat treatments were performed after cutting samples by cold method and before machining of the specimens for mechanical tests (tensile, impact and hardness). Three Charpy and tensile tests per condition were performed, and average values will be presented.

Figure 1 shows the cross section macrograph of the welded joint. Vickers hardness profiles with $10 \mathrm{kgfl}$ load were measured in the positions indicated, i.e., one trail crossing the root pass and other in the region of the cap pass.

Specimens for tensile tests were machined with the sub-size dimensions specified in the ASTM A $370^{18}$. The tensile tests were performed at $22^{\circ} \mathrm{C}$ with constant velocity of $5.8 \mathrm{~mm} \cdot \mathrm{min}^{-1}$, which means an initial strain rate of $0.0048 \mathrm{~s}^{-1}$.

Specimens for Charpy impact tests with sub-size dimensions $\left(10 \times 7.5 \times 55 \mathrm{~mm}^{3}\right)^{19}$ were machined with the $\mathrm{V}$-notch placed in the center line of weld metal in the transversal section. Charpy tests were performed at $-46^{\circ} \mathrm{C}$ and compared to previous results ${ }^{11}$.

The weld metal microstructure was investigated by optical microscope (OM) and scanning electron microscope (SEM) with energy dispersive X-ray spectroscopy (EDS). Vickers microhardness measurements with $50 \mathrm{gf}$ load were performed in the heat affected zone and weld metal near the boundary between then. Metallographic etchings used were (i) $30 \mathrm{ml} \mathrm{HNO}, 10 \mathrm{ml}$ acetic acid, $70 \mathrm{ml} \mathrm{H} 2 \mathrm{O}(1.0-1.2 \mathrm{~V}$, $60 \mathrm{~s})$ and (ii) $10 \%$ chromic acid solution $(2.5 \mathrm{~V}, 30-45 \mathrm{~s})$.

Chemical compositions of the weld metal in the root and cap passes were determined by plasma spectroscopy.

\section{Results and Discussion}

Figures $2 \mathrm{a}$ and $2 \mathrm{~b}$ show the hardness profiles of specimens AW and PWHT-45, respectively. In the as welded condition, peaks of hardness of 355 HV10 are observed in the HAZ of the last pass. This result may be compared to the values of previous works of Zappa et al. ${ }^{7}$ (348 HV1), Ramirez $^{8}$ (301 to 391 HV1), Thibault et al. ${ }^{9}$ ( 380 HV0.1) and Woollin ${ }^{13}$ (312 to 345 HV10). The peak of hardness in the $\mathrm{HAZ}$ decreases with the increase of time at $650^{\circ} \mathrm{C}$, reaching $295 \mathrm{HV} 10$ after 60 minutes, with a more important variation observed between 15 and 30 minutes as shown in Figure 3. Very similar results were obtained in a joint with the same base metal welded with superduplex stainless steel feed metal ${ }^{11}$. The hardness of the weld metal is significantly

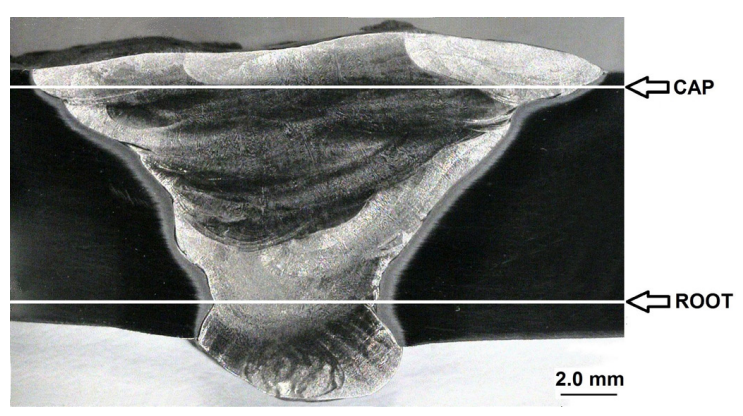

Figure 1. Macrostructure of the welded joint and lines for hardness measurements.

Table 1. Chemical compositions of base (BM) (UNS S41426) and filler (ERNiCrMo3) metals.

\begin{tabular}{cccccccc}
\hline Material & $\% \mathrm{C}$ & $\% \mathrm{Cr}$ & $\% \mathrm{Mo}$ & $\% \mathrm{Ni}$ & $\% \mathrm{~S}$ & $\% \mathrm{P}$ & $\mathrm{Others}$ \\
\hline $\mathrm{BM}$ & 0.0278 & 12.21 & 1.95 & 5.80 & 0.002 & 0.112 & $0.28 \% \mathrm{Ti}$ \\
\hline Filler & 0.0302 & 20.5 & 9.2 & 66.50 & 0.005 & 0.090 & $3.5 \% \mathrm{Nb}$ \\
\hline
\end{tabular}




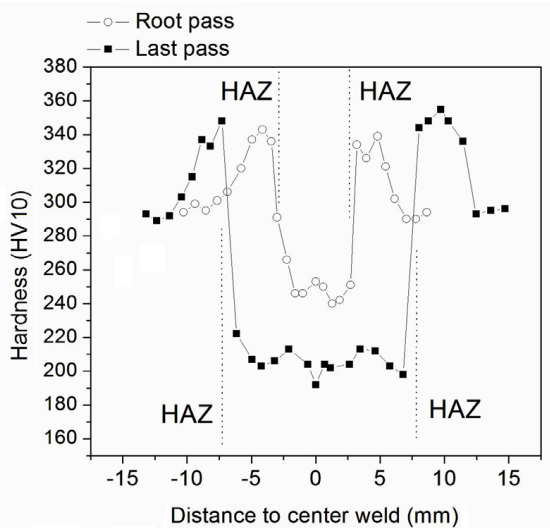

(a)

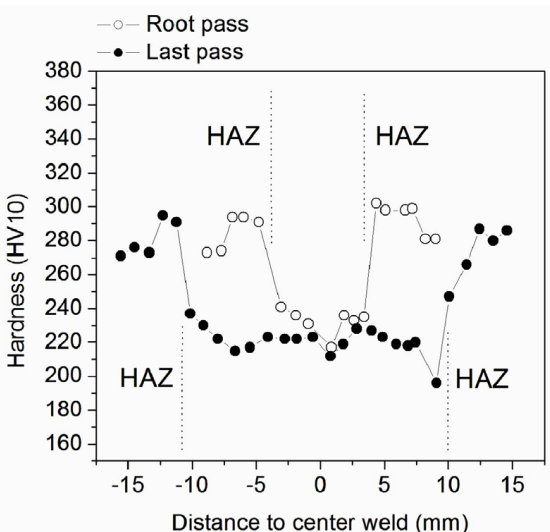

(b)

Figure 2. Hardness profiles: (a) as welded; (b) with PWHT at $650^{\circ} \mathrm{C}$ for 45 minutes.

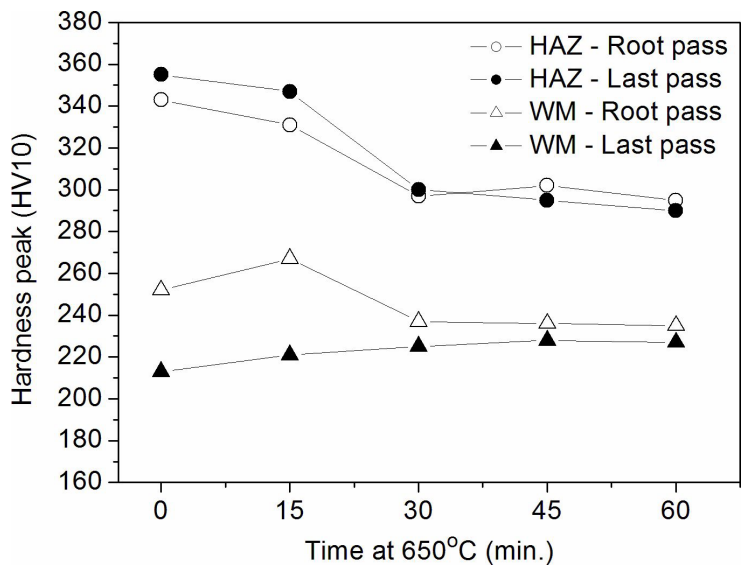

Figure 3. Peak hardness at weld metal (WM) and heat affected zones (HAZ) as function of PWHT time (at $650^{\circ} \mathrm{C}$ ).

Table 2. Samples identification.

\begin{tabular}{cc}
\hline Identification & Processing \\
\hline AW & As welded \\
\hline PWHT-15 & $\begin{array}{c}\text { Welded and heat treated at } 650^{\circ} \mathrm{C}-15 \text { minutes, } \\
\text { water quenching }\end{array}$ \\
\hline PWHT-30 & $\begin{array}{c}\text { Welded and heat treated at } 650^{\circ} \mathrm{C}-30 \text { minutes, } \\
\text { water quenching }\end{array}$ \\
\hline PWHT-45 & $\begin{array}{c}\text { Welded and heat treated at } 650^{\circ} \mathrm{C}-45 \text { minutes, } \\
\text { water quenching }\end{array}$ \\
\hline PWHT-60 & $\begin{array}{c}\text { Welded and heat treated at } 650^{\circ} \mathrm{C}-60 \text { minutes, } \\
\text { water quenching }\end{array}$ \\
\hline
\end{tabular}

lower than the HAZ. The weld metal is slightly harder in the root than in the cap, due to the higher dilution of the root passes.

Figures $4 \mathrm{a}$ and $4 \mathrm{~b}$ show how the tensile properties vary with the PWHT duration. The yield stress and ultimate strength do not vary significantly with the increase of time at $650^{\circ} \mathrm{C}$ (Figure $4 \mathrm{a}$ ). The total and uniform elongation shows an increase with PWHT time, except for a small decrease from 45 to 60 minutes. This may be consequence of the HAZ tempering. All fractures were ductile and always occurred in the weld metal region, as observed in Figure 5 from a specimen heat treated for 15 minutes. It was also observed that the localized plastic deformation was concentrated in the weld metal.

A comparison between the stress-strain curves of the base metal and the welded joint heat treated at $650^{\circ} \mathrm{C}$ for 1 hour is presented in Figure 6. The yield strength of the base metal (670 MPa) was much superior to the welded joints in all conditions, but the ultimate strengths were similar. The nickel alloy 625 has higher work hardenability than the SMSS base metal. As a consequence, although the total elongation of the base metal is higher $(25 \%)$, the uniform elongation of the welded joint is superior. The true stress-strain curves of the base metal and welded joints were modeled by Hollomon's equations $\left(\sigma=K \varepsilon^{n}\right)$, in order to determine the work hardening exponents (n) and the constant $\mathrm{K}$. The $\ln (\sigma)$ versus $\ln (\varepsilon)$ data of the SMSS base metal were fitted by a straight line with slope (n) equal 0.050 (Figure 7a). However, the curves of the welded joint were best fitted by two straight lines,

Table 3. $\mathrm{n}$ and K constants of Hollomon's equation for base metal and welded joint.

\begin{tabular}{ccccccc}
\hline Specimen & $\mathrm{n}_{1}$ & $\mathrm{~K}_{1}(\mathrm{MPa})$ & $\mathrm{R}^{2}$ & $\mathrm{n}_{2}$ & $\mathrm{~K}_{2}(\mathrm{MPa})$ & - \\
\hline Base metal & 0.050 & 1059 & 0.998 & - & $\mathrm{R}^{2}$ & - \\
\hline Weld-as welded & 0.078 & 800 & 0.988 & 0.205 & 1373 & 0.999 \\
\hline Weld-PWHT - 15 min & 0.079 & 809 & 0.990 & 0.197 & 1325 & 0.999 \\
\hline Weld-PWHT - 30 min. & 0.063 & 754 & 0.986 & 0.199 & 1335 & 0.998 \\
\hline Weld-PWHT - 45 min. & 0.074 & 796 & 0.992 & 0.203 & 1356 & 0.998 \\
\hline Weld-PWHT - 60 min. & 0.074 & 845 & 0.993 & 0.191 & 1380 & 0.998 \\
\hline
\end{tabular}




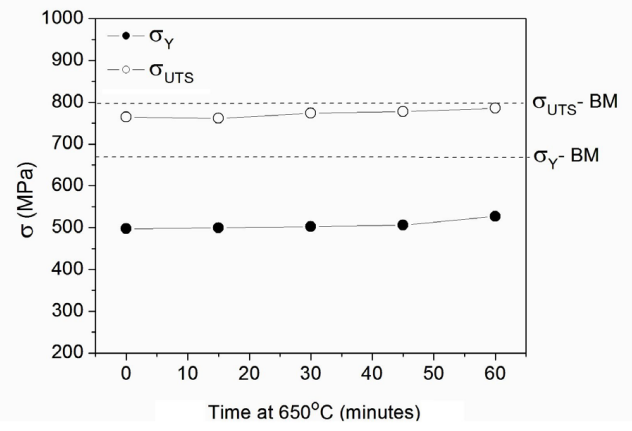

(a)

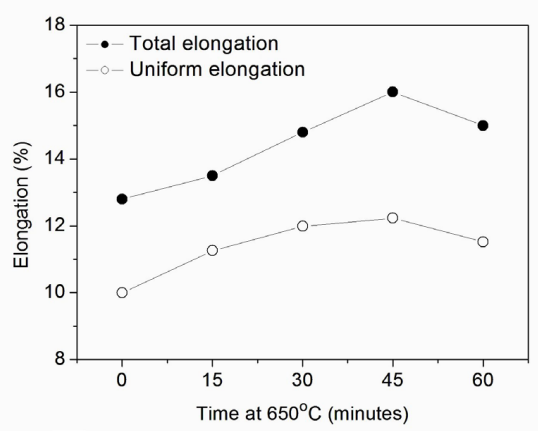

(b)

Figure 4. Variation of tensile properties with PWHT duration: (a) yield $\left(\sigma_{\mathrm{Y}}\right)$ and ultimate strength $\left(\sigma_{\mathrm{UTS}}\right)$; (b) total elongation.

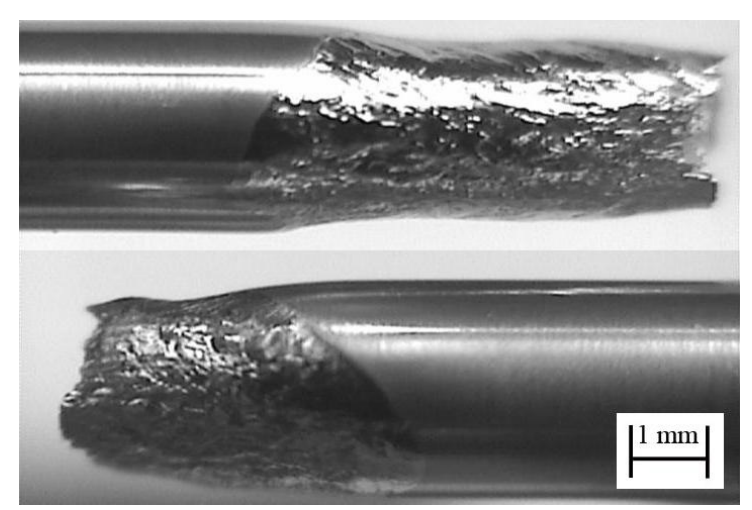

Figure 5. Tensile specimen heat treated at $650^{\circ} \mathrm{C}$ for 15 minutes (after test).

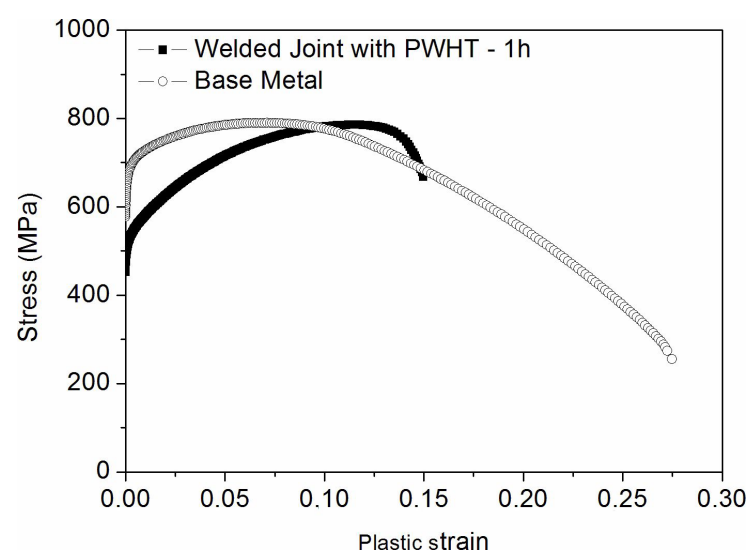

Figure 6. Comparison between tensile curves of the base metal and the welded joint heat treated at $650^{\circ} \mathrm{C}$ for $1 \mathrm{~h}$.

which suggests two work hardening stages. As an example, Figure $7 \mathrm{~b}$ shows the $\ln (\sigma)$ versus $\ln (\varepsilon)$ plot for specimen heat treated at $650^{\circ} \mathrm{C}$ for 15 minutes. Table 3 shows that the work hardening exponents of the welded joint do not vary significantly with the PWHT time, but both $n_{1}$ and $n_{2}$ were superior to the value found in base metal (0.050). Correlation coefficient $\left(\mathrm{R}^{2}\right)$ were also reported in Table 3 .

Charpy tests results are shown in Table 4. The impact toughness of the weld metal with superduplex stainless steel filler metal was included for comparison. As reported in previous work, superduplex stainless steel undergoes
Table 4. Charpy impact tests results for filler metals ER NiCrMo3 (this work) and superduplex stainless steel ${ }^{11}$.

\begin{tabular}{ccc}
\hline PWHT time at $650^{\circ} \mathrm{C}$ & ER NiCrMo3 & Superduplex $^{11}$ \\
\hline 0 & 120 & 136 \\
\hline 15 & 121 & 120 \\
\hline 30 & 126 & 97 \\
\hline 45 & 124 & 51 \\
\hline 60 & 130 & 43 \\
\hline
\end{tabular}

intermetallic precipitation with progressive aging at $650^{\circ} \mathrm{C}^{11}$, and this explains the decrease of Charpy results with the increase of PWHT time. In contrast, the impact toughness of the ER NiCrMo3 was very high in all heat treatment conditions, which is an interesting advantage of using this filler metal.

The best choice for PWHT duration depends on some factors. Short duration PWHT is recommended in two situations: (i) when SDSS is used as filler metal where the increase of exposition time at $650^{\circ} \mathrm{C}$ may provoke intermetallics precipitation in the weld metal ${ }^{1,11}$; (ii) when the pipes are to be welded in field, to increase productivity. Short duration PWHT, for 5 minutes at $650^{\circ} \mathrm{C}$, is effective to reduce the risk of IGSCC, but does not reduce the hardness ${ }^{13}$, as commented. The reduction of the peak of hardness in the HAZ is important to avoid sulphid stress corrosion cracking (SSCC) in services with high $\mathrm{H}_{2} \mathrm{~S}$ and low $\mathrm{pH}$ fluids ${ }^{15}$. In this work, as shown in Figure 3, a significant decrease of hardness in the HAZ is observed in specimens treated for 30 minutes or more. Heat treatment for 15 minutes may be recommended to mitigate IGSCC, but is too short to reduce the risk of SSCC.

Table 5 shows the chemical composition of the weld metal measured in the root and cap passes. The quantities of all alloying elements are similar, except the Fe, which is higher in the root pass. This is expected because the root passes are made with higher heat input which results in higher dilution with the base metal.

The microstructure of the weld metal without heat treatment is shown in Figures 8a-d. The microstructures of the cap and root contain basically $\gamma$ phase and a second phase with higher concentration of $\mathrm{Nb}$ and $\mathrm{Mo}$, which appears light in the image of backscattered electrons (BSE). The $\mathrm{NbC}$ and Laves constituents are the usual secondary phases observed in welds of $\mathrm{Nb}$-bearing alloys. Both of these phases are $\mathrm{Nb}$ rich. 
Table 5. Average chemical composition of weld metal (root and cap passes).

\begin{tabular}{ccccccccccccc}
\hline Region & $\mathrm{C}$ & $\mathrm{Si}$ & $\mathrm{Mn}$ & $\mathrm{P}$ & $\mathrm{S}$ & $\mathrm{Cr}$ & $\mathrm{Mo}$ & $\mathrm{Nb}$ & $\mathrm{Ti}$ & $\mathrm{Fe}$ & $\mathrm{Ni}$ \\
\hline Cap & 0.014 & 0.07 & 0.04 & 0.005 & 0.001 & 20.31 & 9.21 & 3.36 & 0.39 & 3.6 & $\mathrm{Bal}$ \\
\hline Root & 0.013 & 0.07 & 0.05 & 0.005 & 0.001 & 20.26 & 8.93 & 3.26 & 0.38 & 6.3 & $\mathrm{Bal}$. \\
\hline
\end{tabular}

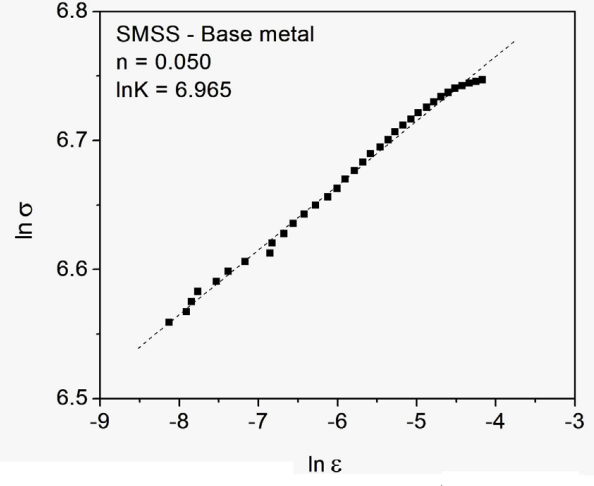

(a)

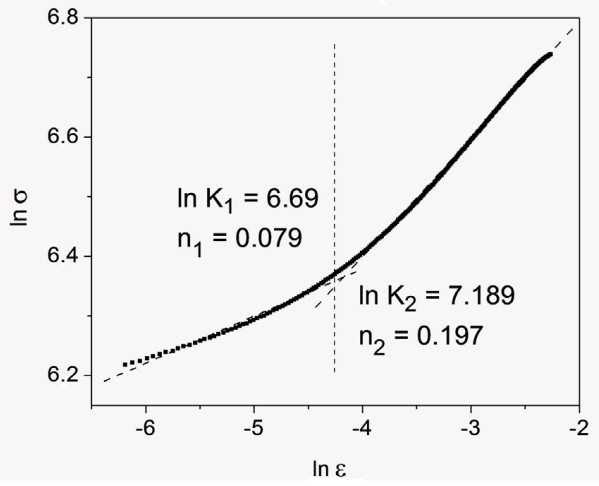

(b)

Figure 7. $\ln (\sigma) \times \ln (\varepsilon)$ of (a) base metal and (b) weld metal heat treated at $650^{\circ} \mathrm{C}$ for 15 minutes.

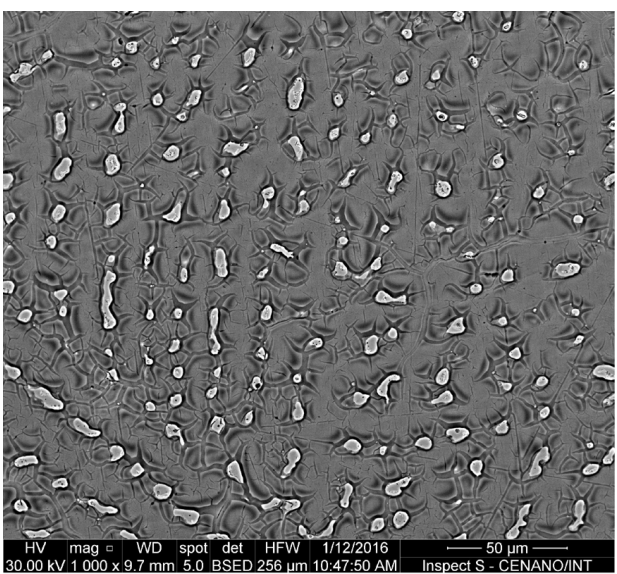

(a)

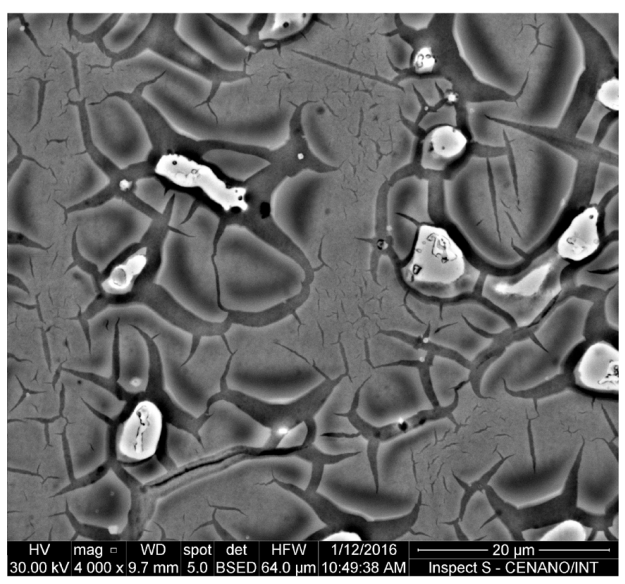

(c)

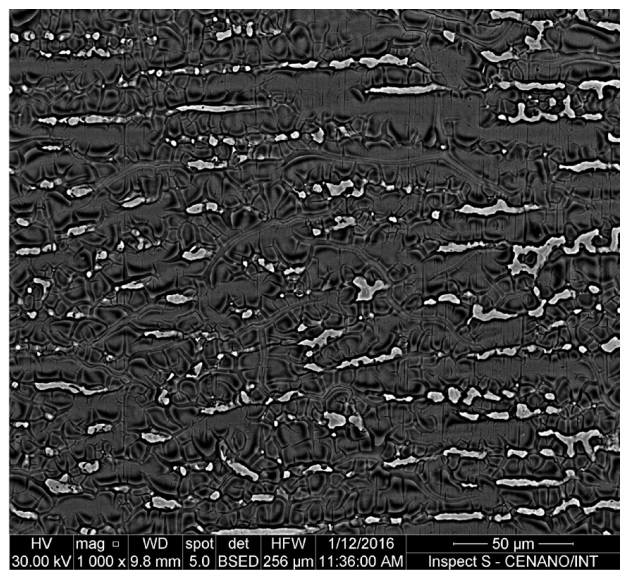

(b)

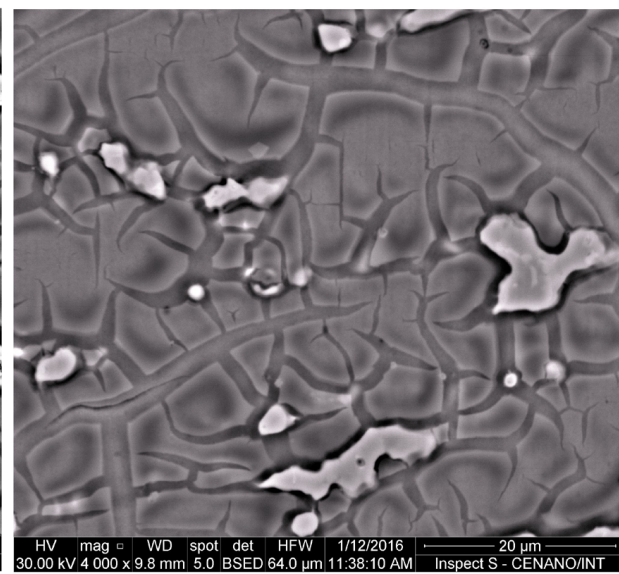

(d)

Figure 8. SEM images of the weld metal: (a-c) root pass; (b-d) cap pass.

According to DuPont et al. ${ }^{20}$, the terminal solidification phase of alloy 625 is strongly affected by the relative amount of $\mathrm{Nb}$ and $\mathrm{C}$ and, to a lesser degree, the Si content. The Laves phase can be prevented when the Si content is low and the $\mathrm{C}$ contents high. In Table 5, the Si and C contents are relatively low in the cap and root passes. Based on the morphology of the second 


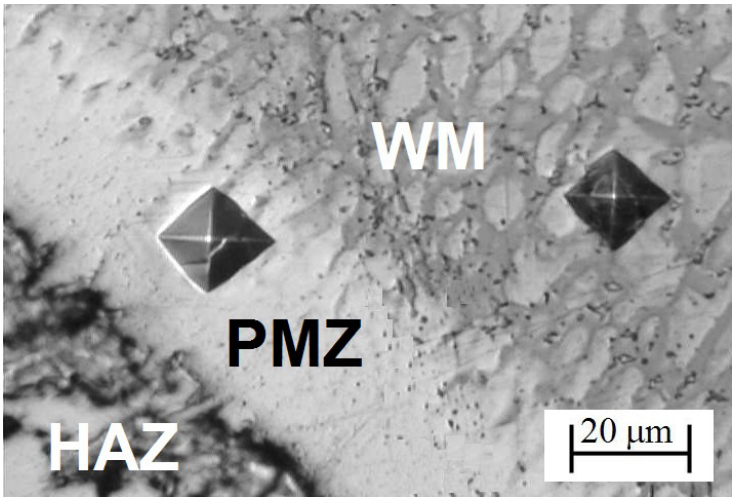

Figure 9. Comparison between microhardness HV0.05 of WM and PMZ.

phases shown in detail in Figures $8 \mathrm{c}$ and $8 \mathrm{~d}$ they correspond to $\mathrm{MC}(\mathrm{M}=\mathrm{Nb}, \mathrm{Mo})$ carbides, and no Laves phase was observed. This phase decreases the toughness of welded metal.

The heat treatments at $650^{\circ} \mathrm{C}$ for periods of time up to 60 minutes did not alter the microstructure of the weld metal. This is in accordance to DuPont et al. ${ }^{20}$, which noticed that no major microstructural change was observed between $600^{\circ} \mathrm{C}$ and $700^{\circ} \mathrm{C}$. It is important to highlight that the PWHT at $650^{\circ} \mathrm{C}$ is carried out to stress relief, improve toughness and decrease the hardness of the HAZ of the base metal (SMSS). Typical temperature of PWHT for the nickel alloy 625 is in the $900-980^{\circ} \mathrm{C}$ range, and the time of treatment must be controlled to avoid or minimize the precipitation of Laves phase $^{20}$. This is a much more complex and expensive heat treatment, which is not applicable in this case.

It is also reported that dissimilar welds between $\mathrm{Ni}$ base alloys and steels also exhibit a composition transition region between the diluted weld metal and the base metal, also called partially melted zone (PMZ). This thin transition region may be martensitic or contain higher alloying contents and, as a consequence, be significantly harder and brittle en $^{21,22}$. Nevertheless, in the present case, as illustrated in Figure 9, the HAZ and the PMZ have similar microhardness. The average microhardness of 10 measurements in the PMZ of the cap passes was $255 \pm 5 \mathrm{HV} 0.05$, against $245 \pm 6 \mathrm{HV} 0.05$ of the adjacent weld metal, which shows that the PMZ is not martensitic.

\section{Conclusions}

A tube of supermartensitic stainless steel with $12 \% \mathrm{Cr}$ was welded with nickel alloy 625 filler metal by manual GTAW process. The main conclusions are:

The welded joint presented lower yield strength than the base metal, but due to the high work hardenability of the nickel alloy the ultimate strength was similar to the base metal.

- $\quad$ Post weld heat treatment (PWHT) at $650^{\circ} \mathrm{C}$ for at least 30 minutes decreased the peak of hardness in the heat affected zone to $\sim 300 \mathrm{HV}$.

- The microstructure of the weld metal consisted of $\gamma$ phase and Mo and Nb-rich carbides. The microstructure and the hardness of the weld metal were not affected by the PWHT at $650^{\circ} \mathrm{C}$.

- The impact toughness of the as weld joint was $120 \mathrm{~J}$, and the PWHT at $650^{\circ} \mathrm{C}$ till 60 minutes sligthly increased this property. This is an advantage over the filler metal of superduplex stainless steel, whose properties are decreased with the increase of PWHT duration.

\section{Acknowledgements}

Authors acknowledge to Brazilian research agency CNPq for financial support (Grant number 314314/2018-0).

\section{References}

1. Lippold JC, Kotecki DJ. Welding metallurgy and weldability of stainless steels. Hoboken: Wiley-Interscience; 2005.

2. Xu L, Shi J, Cao WQ, Wang MQ, Hui WJ, Dong H. Yield strength enhancement of martensitic steel through titanium addition. J Mater Sci. 2011;46(10):3653-8.

3. Silva GF, Tavares SSM, Pardal JM, Silva MR, Abreu HFG. Influence of heat treatments on toughness and sensitization of a Ti-alloyed supermartensitic stainless steel. J Mater Sci. 2011;46(24):7737-44.

4. Tavares SSM, Pardal JM, Souza GC, Oliveira CAS, Abreu HFG. Influence of tempering on microstructure and mechanical properties of Ti alloyed $13 \% \mathrm{Cr}$ supermartensitic stainless steel. Mater Sci Technol. 2014;30(12):1470-6.

5. Carrouge D, Bhadeshia HKDH, Woollin P. Effect of $\delta$-ferrite on impact properties of supermartensitic stainless steel heat affected zones. Sci Technol Weld Join. 2004;9(5):377-89.

6. R. Hoffmann HB. Experiences with supermartensitic stainless steels in the pipe production based on research work and first commercial orders. In: Supermartensitic Stainless Steels 2002; 2002; Brussels, Belgium. Proceedings. Brussels: KCI Publ.; 2002. Paper 018.

7. Zappa S, Svoboda HG, Ramini M, Surian E. Improving supermartensitic stainless steel weld metal toughness. Weld J. 2012;91(3):83.

8. Ramirez JE. Weldability evaluation of supermartensitic stainless pipe steels. Weld J. 2007;86:125.

9. Thibault D, Bocher P, Thomas M. Residual stress and microstructure in welds of $13 \% \mathrm{Cr}-4 \% \mathrm{Ni}$ martensitic stainless steel. J Mater Process Technol. 2009;209(4):2195-202.

10. Neubert V, Reuter J, El-Mahalawy N, Hoffmeister H, Hoffmann R. Effect of welding technique on weld morphology and hardness of supermartensitic $13 \% \mathrm{Cr}$ steels. Mater Sci Technol. 2004:20(12):1551-62.

11. Tavares SSM, Rodrigues CR, Pardal JM, Barbosa ES, Abreu HFG. Effects of post weld heat treatments on the microstructure and mechanical properties of dissimilar weld of supermartensític stainless steel. Mater Res. 2014;17(5):1336-43.

12. Taban E, Kaluc E, Ojo OO. Properties, weldability and corrosion behavior of supermartensitic stainless steels for on- and offshore applications. Mater Test. 2016;58(6):501-18.

13. Woollin P. Post weld heat treatment to avoid intergranular stress corrosion cracking of supermartensitic stainless steels. Weld World. 2007:51(9-10):31-40

14. Pereda MD, Gervasi CA, Llorente CL, Bilmes PD. Microelectrochemical corrosion study of super martensitic welds in chloride-containing media. Corros Sci. 2011;53(12):3934-41.

15.ISO: International Organization for Standardization. ISO 151563:2020: petroleum and natural gas industries: materials for use in H2S-containing environments in oil and gas production. Part 3: cracking-Resistant CRAs (Corrosion-Resistant Alloys) and other alloys. Switzerland: ISO; 2020.

16. Divya M, Das CR, Ramasubbu V, Albert SK, Bhaduri AK. Improving 410NiMo weld metal toughness by PWHT. J Mater Process Technol. 2011;211(12):2032-8. 
17. Bilmes P, Llorente C, Pérez Ipiña J. Toughness and microstructure of 13Cr4NiMo high-strength steel welds. J Mater Eng Perform. 2000;9(6):609-15.

18. ASTM: American Society for Testing and Materials. ASTM A370-19: standard test methods and definitions for mechanical testing of steel products. West Conshohocken: ASTM; 2019.

19. ASTM: American Society for Testing and Materials. ASTM E23-18: standard test methods for notched bar impact testing of metallic materials. West Conshohocken: ASTM; 2018.
20. DuPont JN, Lippold JC, Kiser SD. Welding metallurgy and weldability of nickel-base alloys. New Jersey: John Wiley \& Sons; 2009.

21. Silva CC, Afonso CRM, Ramirez AJ, Motta MF, Miranda HC, Farias JP. Aspectos metalúrgicos de revestimentos dissimilares com a superliga a base de niquel Inconel 625 . Soldag Insp. 2012;17(3):251-63.

22. Prabaharan P, Ramkumar KD, Arivazhagan N. Characterization of microstructure and mechanical properties of Super Ni 718 alloy and AISI 316L dissimilar weldments. J Mater Res. 2014;29(24):3011-23. 